\title{
Review of Rural Policing and Policing the Rural: A Constable Countryside? Rob I. Mawby and Richard Yarwood (Eds.)
}

\author{
Routledge (first published by Ashgate) \\ ISBN: 9780754674733
}

\author{
Reviewed by Scott K. Turner \\ West Virginia University, Morgantown, WV, USA \\ skt0008@mix.wvu.edu
}

Rural Policing and Policing the Rural: A Constable Countryside? is a substantive compendium of rural policing and rural crime articles situated in Western countries throughout the globe. Research from Canada, the United States, Australia, Scotland, England, France, Africa, and New Zealand is presented in an eye-opening, thought provoking fashion. For the newcomer to rural studies, the book is a foundation and framework for future research. To the scholar, it builds upon the impressive body of previous work and sets the stage for new advances. The book astutely challenges the idyllic portrait of the countryside, small town police, and rural life.

In challenging the idyllic portrait of the countryside, the reader is confronted with his own perceptions of rurality. Perceptions that are likely to include lakes, forests, rivers, open fields and green space. Yet, there is another side of rural, beyond perception, based in reality, grounded in crime. Rural crime comes in many forms; property (damage and theft), environmental (wildlife and pollution), and the myriad of personal crimes (assault, rape, murder, drugs, fraud). Violence against women is a particularly troubling issue that seems to be prevalent in rural communities. Farm crime is another major concern where spatiality and geography help to create opportunities to commit or conceal deviance. Drugs crimes, once thought to be an urban problem, have become pandemic in rural places begging the question, "Why?"

Small town policing of rural spaces is challenged in the book too. The chapters include vibrant discussions of police structures, practices, and the evolution of police over time. Here, readers can draw upon similarities between the French Gendarmerie and American state police organizations. Or, they can contrast the Royal Canadian Mounted police with policing on the Isle of Jersey in the U.K. Structurally and culturally all of these organizations have been shaped by broader social issues and their place in rural spaces. The outcome of those forces has been an evolution towards centralization at the national or regional level in many places; a curious turn of events in the era of community policing. What also comes through in the chapters is that policing is a much broader concept in rural communities. It may or may not include the public police, noting that there is a network of voluntary controls and standards that residents enforce themselves. The chapters also share a range of unique case studies, police community 
partnerships, some of which have become institutionalized others that have only recently been implemented.

Rural life is given rich context in each of the chapters. It is idyllic at times and the book helps to remind us of that truth. Though, as the reader becomes conscious of the issues rural people face, idyllic comes to mean something else entirely. Rural spaces are filled with challenges; lack of services, unemployment, low educational attainment, and poverty to name a few. Each of these socio economic factors has been associated with crime and can mean the difference between the "good places to live" and the other. The good places have resources and residents who are socially, culturally, and economically healthy. The other rural spaces exist in conflict where crime is merely a symptom of the broader societal forces at work. Even in the good places to live, class struggles and lifestyle choices can cause conflict as evidenced by the chapters on gypsies and travellers. Rural life is far from simple. It is complex and multidimensional.

Chapter 1, the "Introduction," by Rob I Mawby and Richard Yarwood shares a broader view of rurality with the reader through a discussion of culture, space, and economy. The book is also laid out in two separate parts. Part I, presents rural police systems existing in different regions of the world from a cultural and structural perspective. Readers are exposed to the historical and evolutionary perspectives of the field. It is a window into the past in rural policing that helps us to understand why change and evolution are being sought. Part II, describes uniquely rural crime types and the challenges confronted by rural police and their communities. In those places, space and time can be significant variables in crime or challenges. The book concludes with a vibrant discussion on the future of rural policing and rural crime research.

Chapter 2, "Rural Police: A Comparative Overview," by Rob. I Mawby, is a baseline for the section, offering a historical perspective of policing in western countries. Mawby reveals that police systems in many rural areas were primarily a response to a perceived need to control aboriginal and mining populations. Formed out of conflict, the social and political components of those agencies comes to light. Centralization and decentralization of police operations in local, regional, and national systems are also examined. The chapter concludes with a discussion of the local nature of crime and whether a local or national force is better suited for the task.

The structural and economic factors that shape rural crime in the U.S. and Canada come into view in Chapter 3, "Policing Rural Canada and the United States." Here, Joseph Donnermeyer, Walter DeKeseredy and Molly Dragiewicz reveal the two faces of rural Canada and the United States; areas that are steeped in poverty, others that most would consider good places to live. This dichotomy is a part of the broader social reality in rural life that often goes unnoticed. It is an invisible reality, not captured in the idyllic paintings of Norman Rockwell or 
Thomas Kinkade. The chapter also examines the relations between rural police, Native Americans, and the "web" of local, state, and federal policing agencies. The article concludes with a call for research designed to unravel the social and economic structures in rural life and community.

Spatialization is explored on the vast Australian Outback in Chapter 4, "Policing the Outback: Impacts of Isolation and Integration in an Australian Context" by Elaine Barclay, John Scott, and Joseph Donnermeyer. The spatial influences on normative frameworks of rural police are discussed in great detail. For example, the researchers report that rural police culture is quite distinct from urban police and that their attitudes towards their work and the community are generally positive. The reader is also prompted to consider police relations with indigenous populations, noting their over-representation in crime statistics. It is an important consideration, perhaps one that has been overlooked in much of the research, enlightenment that is sure to make one think. The article moves on with a discussion of family violence, noting its significance in the region and impact on policing who rather than policing public space have now been called upon to police private space; the family. The article concludes with a recognition that policing on the outback is undergoing change, new training, implementation of aboriginal police, and new partnerships to address what matters most, victims' needs.

Chapter 5, "Rural Policing in France: The End of Genuine Community Policing" by Christian Mouhanna provides a rich, contextual history of the French Nationale Police and Gendarmerie Nationale Police. Interestingly, both organizations are consolidated under a single Police Nationale, but they retained their separate identity, purpose and structure. The Gendarmerie operates as a military force to police rural communities throughout the countryside. Mouhanna, labels them the "real community police" citing their close relations with rural people, informal methods of dispute resolution, and living arrangements within the towns and villages they police. The French National Police functions as the civilian counterpart to the Gendarmerie, policing France's cities. The articles follows the evolution of the Gendarmerie over the decades and its evolution as the social forces of bureaucracy, modernism, and consolidation smoothing over the distinctions of the two agencies with the "old" Gendarmerie becoming a relic of the past. Itis an intuitive perspective of police evolution and to a degree of society.

The section continues with three more chapters/articles on rural policing in the United Kingdom. In Chapter 6, "Plural Policing in Rural Britain," Rob I. Mawby reveals the developing trend of volunteer policing in rural Britain. He challenges the myth that policing has expanded universally in rural and urbans spaces and the similar nature of that expansion. Instead, he examines data from the British channel islands to reveal a different picture. Mawby's work reveals first and foremost that policing has become an institutionalized community endeavor where volunteers, service partners, and public police have shared responsibilities. This is a 
much broader concept of policing as discussed in Chapter 1. Daniel Gilling discusses rural crime "governance" in Chapter 7, "Governing Crime in Rural UK: Risk and Representations." Like Mawby, Gilling finds that policing is bound by the combined efforts of police, public private partnerships and the community. He explains that this new way of policing has been driven by the failure of public police to stem the tide of crime. Gilling also challenges the idyllic countryside by elaborating on the "Endangered," "Frightened," and "Deprived" rural places. Chapter 8, "Big Brother Goes to the Countryside: CCTV Surveillance in Rural Towns," by Craig Johnstone continues the theme that policing is much more than public police. Johnstone engages the reader with the practical implications of CCTV in rural communities and how this new technology is being used to help prevent crime, enhance safety, and deter anti-social behavior. One of the practical implication in the article is how should rural police incorporate CCTV into their strategies in light of limited resources and what would it look like if they did? Remarkably, the use of this new technology in some town has led others to believe that they need it too, despite relatively low levels of crime in those spaces. CCTV in rural communities is a topic that is ripe for further discussion and research.

Part I closes with a piece by one of the editors, Richard Yarwood, "Whose Line is it Anyway? Community Policing and Partnership Working in Rural Places." Partnerships and governance are given further treatment with a look to England, West Australia, and New Zealand. What is evident is that community ties and community policing are at the forefront of contemporary practices in each of these regions. In addition, volunteer or aboriginal patrols exist to supplement understaffed public police revisiting the broader meaning of policing. Yarwood concludes the article with a recognition that despite a somewhat renewed interest in rural policing by researchers, interest among policy makers has been weak, coinciding with funding deficiencies.

Part II of this book examines the variety of crime types found in rural communities, challenges posed to police and residents, and the broader meaning of policing rural spaces. The section opens with a discussion of rural protest, a particularly relevant topic in the U.S. in recent years as anti-hunting, anti-development, anti-mining, and anti-drilling groups have gained momentum. The section also examines conflict between groups; indigenous people $\mathrm{v}$. the new majority population, rural residents vs. travellers and gypsies. Here too, parallels can be drawn as van dwelling vagabonds take to the streets and rural places. The insidiousness of domestic violence is revealed in greater detail as well. Farm crime, agricultural conflict, wildlife, and politics are also discussed in the section suggesting that there is much more to consider in the study of rurality.

Chapter 10, "Policing Rural Protest," by Michael Woods is a retrospective study of analyzes rural protests dating back to the 1970s. It also provides a socio legal analysis of how laws enacted for the purpose of limiting disruption caused by protesters are now used to remove 
trespassers, i.e. travellers from rural communities. The article also addresses changes in police practice from keeping the peace to law enforcement. Chapter 11, "Still, 'out in the country'? Travellers and Post-Productivist Rural," by Keith Halfacree expands on the topic of travellers and how they are viewed by locals and police. The article explains post World War II plans for the countryside and how it helped to create conflict between residents and the traveller community. Chapter 12, "Gypsies and Travellers in the Countryside: Managing a Risky Population," by Zoe James discusses the results of a needs assessment by local officials which provided a comprehensive picture of the Gypsy and Traveller population in England. The findings were that the travelling population rely on unauthorized encampments and are regularly evicted by police creating conflict between the two groups. All three articles reveal a population in rural communities beyond the traditional landowner who are at risk or deemed a risk depending on which groups is being represented.

Rural drug use is explored in Chapter 13, "A Trip in the Country? Policing Drug Use in Rural Settings" by Adrian Barton, David Storey, and Claire Palmer. This seemingly urban dilemma has infected rural communities across the globe for decades despite the stereotype that it is an urban problem. Once again, the reader is prompted to confront the idyllic view of the countryside to face the reality of rural life. The researchers examined two rural communities in England and Wales to explain how "user circles" ensured access to illicit substances for addicts. For the casual user without a "user circle," getting a high became much more difficult and risky. The article also addresses how police have changed their response to drug crimes; less law enforcement, greater intervention of social, medical and welfare agencies. The study is a reaffirmation of one of the books themes, policing is a community activity, not merely a responsibility of the public police.

“It's Not All Heartbeat You Know: Policing Domestic Violence in Rural Areas," by Greta Squire and Aisha Gill, Chapter 14, is situated in the U.K. The study reveals the role of myths and stereotypes in dismissing "invisible crime" like domestic abuse in rural spaces. It also exposes how police downplay the problem endangering women in the process. The article details reforms like pro arrest policies for abusers and a change in attitude and buy in from police, but finds these changes to be inadequate. The role of a special domestic violence unit in the community is also highlighted. Despite the reforms, funding remains a significant issue as cities continue to receive the bulk of the support. The research concludes with recommendations, including, safety planning for women who need to escape.

Chapters 15 by Nicholas R. Fyfe and Alison D. Reeves, is a Scotland study, "The Thin Green Line? Police Perceptions of Challenges of Policing Wildlife Crime in Scotland." Whereas, Chapter 16 by A. M. Lemieux, takes place in Africa, "Policing Poaching and Protecting Pachyderms:Lessons Learned from Africa's Elephants." Both studies reveal what is truly rural, wildlife crime, but with an urban nexus of global trade. In Africa, the global trade in animals, 
animal parts, poaching and fauna threaten entire species and pose an insurmountable challenge to local police. Worse, offenders often come from local towns and villages poaching as a means of survival. Spatial characteristics, global trade, and economic pressures require a global police response. In Scotland, the government policy is to treat wildlife crime like any other crime. Partnerships with the local community to protect the environment seems to be a top priority. Although spatial characteristics are still a problem, global trade and economic pressures are less as compared to Africa and the problem is in country.

In Chapter 17 Joseph Donnermeyer, Elaine M. Barclay and Daniel P. Mears present "Policing Agriculture Crime," by drawing upon victimization studies from the UK and U.S. The study also incorporates responses to agricultural crime in Australia and California and identify a number of social, environmental, and structural factors involved. One finding of the study was that crime could be reduced by limiting opportunities for crime and increasing the number of guardians. A rather important revelation in the study was that topography had a place in rural crime. Chapter 18 also addressed agricultural crime, "Policing the Producer: the Bio Politics of Farm Production in New Zealand's Productivist Landscape," by Matthew Henry added another dimension to the research, politics. Like the article on domestic abuse, the economic and political realities that accompany the acquisition of land from indigenous people is disturbing. Henry follows the land from colonization, stripping forests into fields, and the development of large scale, state sponsored farms. This production model has made New Zealand a global food producer, but at what cost. Policing the production of food is a task reserved for a new army of state inspectors who are further alienated from the original people. The article may foreshadow alienation from the land in other developing nations.

Rural Policing and Policing the Rural: a Constable Countryside? concludes with Chapter 19 "W(h)ither Rural Policing?: Afterword by the editors Richard Yarwood and Rob I.

Mawby. The chapter provides a recap of some of the main themes discussed throughout the book; who is policing rural communities, what is rural, and who are the insiders and outsiders in rural spaces. It concludes with a call for additional research of rural police and crime globally.

This book review has been an enjoyable trip into the countryside; an intellectual journey of sorts into rurality, rural crime, and rural challenges. Section by section, article by article, I found myself nodding in agreement, captured by another's insight, inquisitive to learn more. I was struck by the "modern" centralization vs. decentralization debate presented by Mawby in Chapter 2, realizing that the very same issues were debated in the U.S. during the early part of the 20th and led to the creation of state police to supplant supplant rural sheriffs. At that time, centralization stopped at the boundaries of the cities where urban police maintained their independence from central administrators. Donnermeyer, Dekeseredy, and Dragiewicz discussion of rural police in Canada and the U.S. revealed the vestiges of that era and went beyond by peering into the differential, social, and economic aspects that police work defined. 
Christian Mouhanna's representation of the French Gendarmerie as the end of community policing was also enlightening. He told the story of how the Gendarmerie had become part of the community, in large part based on their relations, but with centralization all of that would soon change. Mouhanna grasped the nature of those police community relations in rich, context. Yet, that same understanding seemed beyond what the bureaucratic mindset could fathom. I was also intrigued by the strategies that were undertaken in the U.K. There, policing as a community responsibility was on full display through volunteers and partnerships leading me to wonder if the future will prove the past.

Squire and Gill's study on rural domestic violence is an insightful reading that describe how rural life, myths and stereotypes can be used to dismiss violence against women. It also helped to illustrate the challenges posed to police and victims by time and distance. The articles on gypsies and travellers, by James, Halfacree, and Woods, were also of great interest and they were relevant to understanding issues regarding a U.S. phenomenon called van life. That gets me to another important point about the book! Studies from the U.K., Australia, France, or Africa are relevant to researchers globally giving the book a whole other dimension in scholarship. The book continually prompts the reader to think and think critically about rural crime, rural life, and the social forces intertwined; inequality, spatiality, structure and so many more that might be invisible to the reader in the introduction, yet opaque by the conclusion. The reader will never look at rurality the same way again. Rural Policing and Policing the Rural: A Constable Countryside lands on my must read list! 